\title{
Schools Proximity to Plantations de Haut Penja, Learners' Attitudes and Incidence of Pesticide Contamination in Cameroon
}

EFUETLANCHA Ernest NKEMLEKE ( $\nabla$ nkemleke50@yahoo.com )

University of Dschang: Universite de Dschang https://orcid.org/0000-0002-7586-7456

Kuété Martin

University of Dschang: Universite de Dschang

\section{Research Article}

Keywords: Pesticide, proximity, contamination, learners' attitude, PHP, Cameroon

Posted Date: March 16th, 2021

DOl: https://doi.org/10.21203/rs.3.rs-294663/v1

License: (c) (1) This work is licensed under a Creative Commons Attribution 4.0 International License.

Read Full License 


\title{
Schools Proximity to Plantations de Haut Penja, Learners' Attitudes and Incidence of Pesticide Contamination in Cameroon
}

\author{
Efuetlancha Ernest Nkemleke ${ }^{1 *}$ \& Kuété Martin ${ }^{1}$
}

\begin{abstract}
Learners at school can be subjected to pesticide exposures both from use in the schools and from nearby operations. Plantations de Haut Penja (PHP) is an agro-industrial plantation that uses pesticides to spray its bananas (Musa spp) using helicopters. This aerial spray couple with air drift of noxious particles exposes learners in nearby schools to acute and chronic effects. This paper sought to compare learners' attitudes with regards to pesticide, in schools located closer to, and further away from the PHP as well as the incidence of contamination among the latter. Data was collected from 600 learners across 10 secondary schools in two subdivisions. Analysis was done with Microsoft Excel 2016 and Statistical Package for Social Sciences (SPSS) 16.0 software. Findings depicted that schools are located $5 \mathrm{~m}$ away from the PHP where pesticides are used on a daily basis. Hence, this exposes learners to the harmful effects of these chemicals. Wind was perceived as the main driver of pesticides drift into schools as it blows from the south west direction at a maximum speed of $30 \mathrm{~ms}^{-1}$ which facilitates the drifting of airborne particles of pesticides. As a result, learners closer to the PHP are more vulnerable than their counterparts further away. Kruskal-Wallis test depicted that learners are also involved in pesticides related activities due to a plethora of reasons which further broadens the incidence of contamination among the latter. The study concludes that an environmental impact assessment be carried out in order to install wind barriers in the PHP to prevent spray drifts from entering into schools and that, the Ministry of Agriculture and Rural Development (MINADER) with its decentralized units, should ensure strict implementation of the legal framework on pesticide use and the development, application and evaluation of government policy in the domain of agriculture and environmental surveillance for the proper management of pesticides in Cameroon.
\end{abstract}

Keywords: Pesticide, proximity, contamination, learners' attitude, PHP, Cameroon

1 Department of Geography, Planning and Environment, Faculty of Letters and Social Sciences, University of Dschang, Cameroon.

*Corresponding author: Efuetlancha Ernest Nkemleke, Email: nkemleke50@yahoo.com

Tel: $+\mathbf{2 3 7 6 7 4 7 1 0 5 1 3}$

1 Department of Geography, Planning and Environment, Faculty of Letters and Social Sciences, University of Dschang, Cameroon. Email: kuetemartin52@yahoo.fr 


\section{Introduction}

From the early 1990s till present, there have been many concerns about children's exposure and potential health risks related to pesticides around the world (US EPA, 2007). Therefore, the risks of exposure by human population from minor environmental contamination, however, largely go unnoticed. This is due to a dealt in literature on the relationship between residential and schools proximity to agricultural areas where Plant Protection Products (PPP) are used and children's exposure within these agricultural holdings. These PPP are seen as chemical substances whose active ingredients are capable of killing or destroying, repelling pests and diseases on plants as well as regulating plants growth (FAO \& WHO, 2014). Therefore, these active ingredients are grouped under diverse chemical groups, some of which are more or less toxic than others and are capable of reacting with the body metabolism and causing harm.

Scholars have stressed on the correlation between pesticides and school-aged children or school going population (Curwin et al. 2007; Morgan, 2012) and hold the idea that, people who live closer to agricultural holdings are likely to be affected than people who live in non-agricultural zones. Other authors see school going population as a potentially vulnerable population to the harmful effects of PPP through a plethora of factors or drivers such as proximity to sprayed farmlands, learner's age, gender and take home pesticides by parents or household heads (Lu et al. 2000; Petchuay et al. 2006; Curwin et al. 2007; Panuwet et al. 2009; Morgan, 2012; Rohitrattana, 2014; Nkemleke \& Kuété, 2020). Environmental factors are also responsible for pesticides drift to undesired areas. These factor among others are; the weather conditions at the time of application (i.e. wind speed and direction, temperature, relative humidity, and stability of air at the application site), methods of application, type of equipment, techniques used and spray characteristics (Miller, 1993; Miller \& Smith, 1997; Ghosh \& Hunt, 1998; Miller \& Butler, 2000; De Jong et al. 2000; Womac et al. 2000; Van de Zande et al. 2003; Gil \& Sinfort, 2005; Nuyttens et al. 2007; Yi, 2008; Baetens et al. 2009; Hanna \& Schaefer, 2014; Graeme, 2017; Balsari et al. 2019; Baio et al. 2019; Desmarteau et al. 2019).

In agricultural holdings where pesticides are used on a daily basis, people may be affected through inhaling residues from drift and volatilisation. Other incidences of contaminations are triggered by dermal contacts and ingestion during pesticides application or in the long run, from residues that ooze into soils, accumulates in crops, or seep to groundwater (Brody et al. 2002). Similarly, Muir et al. 2004 have stressed on the ease with which some pesticides compounds undergo short-range atmospheric volatilisation to ecological regions. This is why other findings depict that in studies pertaining to exposure assessment process for quantifying pesticide exposures, it is imperative to define the population under survey, characterise temporal variation in patterns of pesticide use, determine the source of exposure (rate and method of application), and identify possible exposure pathways (residential proximity to the chemical hazards).

Pesticide poisoning and/or incidence of pesticides contamination has been a major health concern in Cameroon. Unfortunately, this problem has not been well documented, due principally to inadequate information and the poor understanding of its implications. The PHP, being an agroindustrial banana plantation in Cameroon, grows banana on the rich volcanic soils of the coastal lowlands of Cameroon mainly for export. As one of its primordial goals is to increase output, this plantation uses large quantities of pesticides on its bananas. Pesticides application is done on daily bases to spray bananas with the use of helicopters through aerial application. However, spray drifts from these banana estates get into residential areas and/or school yards which are located within 5 to $100 \mathrm{~m}$ from these plantations; thereby exposing the entire population to the 
harmful effects of these pesticides. School going population (students) who live closer to the PHP and those who attend school located closer to these banana estates are no exception.

80 It is worth stressing at this juncture that the problem posed in this research is somewhat state-of81 the-art because as most research findings have focused on the health related issues of PPP on farmers and other users, this study looks at the potential exposure and/or contamination of a neutral population (school going population) to these PPP. Thus, the main objective of this present research was to show that apart from farmers who use pesticides on a daily basis, school going population especially those living closer to agricultural holdings are more vulnerable to the harmful effects of pesticides use in these holdings. Hence, the study sought to attain the following objectives: to identify schools located closer to and further away from the PHP banana estates; to assess learners' attitudes/practices vis-à-vis some pesticides related activities closer to and further away from the PHP; and to identify the age group more likely exposed to PPP among school going population and the resultant effects of these toxic chemicals on them. This study also hypothesizes that school going population is potentially exposed to the noxious effects of PPP use in nearby agro-plantations.

\section{Materials and Methods}

\section{$95 \quad$ 2.1. Study site}

96 The Mungo Division in the Littoral Region of Cameroon is where the study was conducted (Fig 97 1). This division is situated between $4^{\circ} 30^{\prime} \mathrm{N}$ and $4^{\circ} 43^{\prime} \mathrm{N}$ of latitudes, and $9^{\circ} 35^{\prime} \mathrm{E}$ and $9^{\circ} 54^{\prime} \mathrm{E}$ of 98 longitudes. The Mungo Division is separated from the western highlands of Cameroon at the 99 lower course of the river Mungo where the division got its name. This division stretches and occupies a south-north direction over a distance of approximately $140 \mathrm{~km}$ (latitude $4^{\circ}$ to $5^{\circ} \mathrm{N}$ ). 


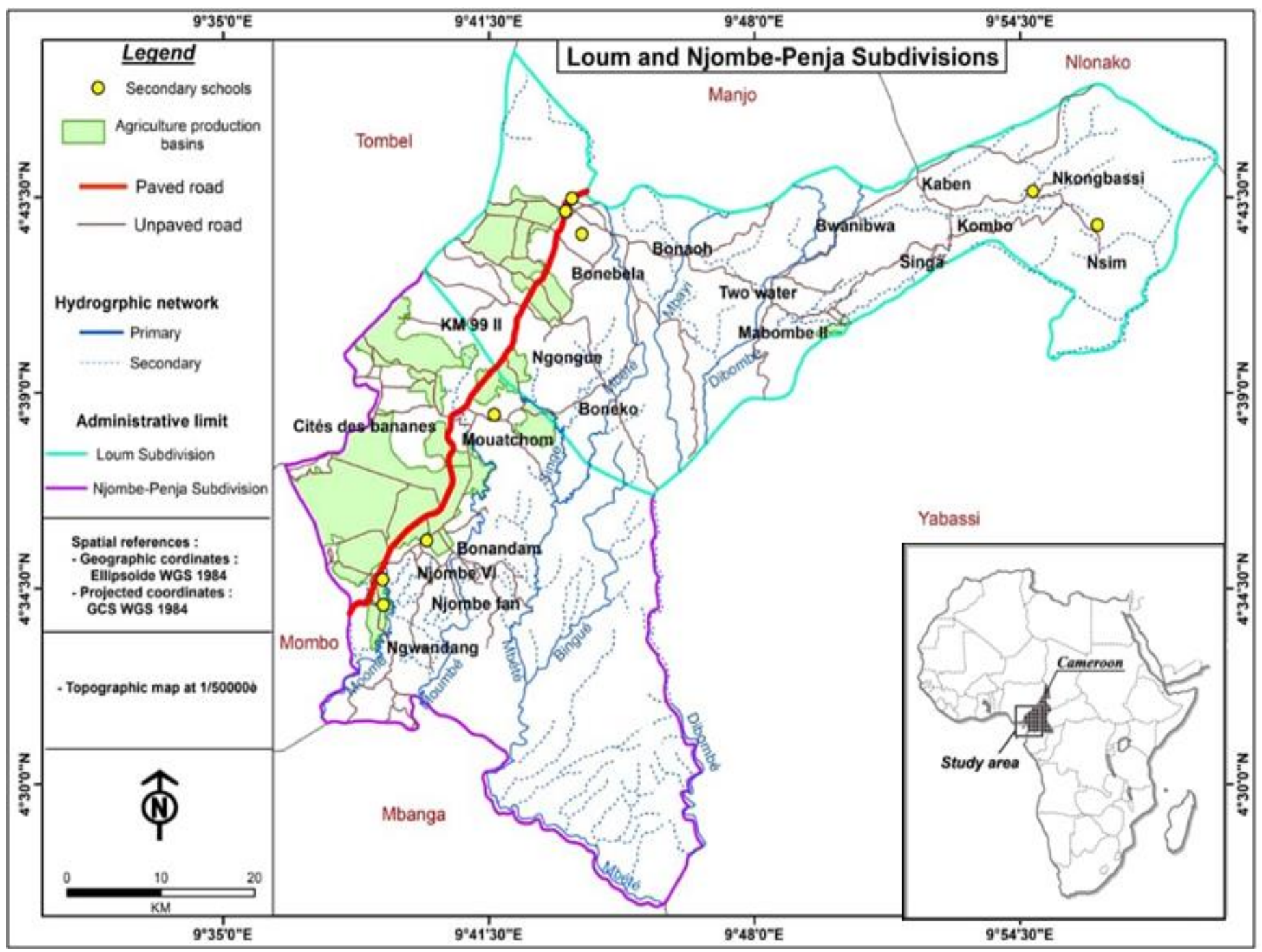

Source: National Institute of Cartography 2018 and field work. Drawn by: Ernest Nkemleke

The rainfall amount in this area stands $>2000 \mathrm{~mm}$ but shows some significant variability (augmentation) which is witnessed in Njombe $(2700 \mathrm{~mm}$ of rainfall) and in Penja (3000mm of rainfall), (Nkemleke \& Kuété, 2020). The rainy season begins from March extending right to October. The dry season on its part, lasts only three months (October to January) and it is more observed in the north than the south of the Mungo Division. The temperature is between $22^{\circ} \mathrm{C}$ and $24^{\circ} \mathrm{C}$ in the Southern and Northern parts of the Mungo Division respectively. This study was conducted in the three major settlements of Loum, Penja, and Njombe in the Mungo Division.

\subsection{Sampling}

Diverse sampling procedures were used in this research. At the first phase, the study site was chosen due principally to the fact that school going youths are more and more engaged into pesticides related farming activities and this exposes them to the negative effects of these chemicals because of their limited knowledge, training in pesticides use and proximity of schools to agro-industrial banana plantations. At the second place, the study area was divided into two strata and stratified random sampling was used wherein, schools going youths were selected 
based on the proximity of their schools to agro-industrial plantations. The schools under survey were GBHS Manengwassa, GBHS Penja, GBHS Njombe, GSS Babong, SAR/SM Badjokip, Collège des Arts et Métiers (CAMEL), Lycée Technique de Loum, TISSERINS, CETIC de Njombe-Penja and Collège Polyvalent (Table 1).

Ultimately, the last phase involved interviews with key informants like heads of institutions and health personnel and other resource persons to ascertain the authenticity of the responses sourced from learners during surveys with questionnaires. Through questionnaires, 600 learners from ten (10) government and private secondary schools were interviewed with a $100 \%$ respondents' rate.

Table 1: Selected schools and geographic coordinates with sampled learners

\begin{tabular}{lcccc}
\hline School & Latitude & Longitude & Altitude & $\begin{array}{c}\text { Learners } \\
\text { sampled }\end{array}$ \\
\hline GBHS Manengwassa & $4^{\circ} 43^{\prime} \mathrm{N}$ & $9^{\circ} 43^{\prime} \mathrm{E}$ & $\begin{array}{c}345 \text { metres above sea } \\
\text { level-masl }\end{array}$ & 60 \\
\hline CAMEL & $4^{\circ} 43^{\prime} \mathrm{N}$ & $9^{\circ} 44^{\prime} \mathrm{E}$ & 359 masl & 60 \\
\hline Lycée Technique Loum & $4^{\circ} 42^{\prime} \mathrm{N}$ & $9^{\circ} 43^{\prime} \mathrm{E}$ & 368 masl & 55 \\
\hline SAR/SM Badjokip & $4^{\circ} 42^{\prime} \mathrm{N}$ & $9^{\circ} 58^{\prime} \mathrm{E}$ & 335 masl & 45 \\
\hline GSS Babong & $4^{\circ} 43^{\prime} \mathrm{N}$ & $9^{\circ} 55^{\prime} \mathrm{E}$ & 350 masl & 40 \\
\hline TISSERINS & $4^{\circ} 34^{\prime} \mathrm{N}$ & $9^{\circ} 35^{\prime} \mathrm{E}$ & 289 masl & 60 \\
\hline GBHS Penja & $4^{\circ} 38^{\prime} \mathrm{N}$ & $9^{\circ} 41^{\prime} \mathrm{E}$ & 235 masl & 30 \\
\hline CETIC de Njombe & $4^{\circ} 36^{\prime} \mathrm{N}$ & $9^{\circ} 40^{\prime} \mathrm{E}$ & 278 masl & 65 \\
\hline GBHS Njombe & $4^{\circ} 35^{\prime} \mathrm{N}$ & $9^{\circ} 40^{\prime} \mathrm{E}$ & 340 masl & 135 \\
\hline Collège Polyvalent Penja & $4^{\circ} 38^{\prime} \mathrm{N}$ & $9^{\circ} 41^{\prime} \mathrm{E}$ & 260 masl & 50 \\
\hline Source: Field
\end{tabular}

Source: Field work, 2019

\subsection{Data Collection and Analysis}

Both primary and secondary data were used for the study. Primary data was collected from 600 students in ten (10) schools. This was done through the administering of questionnaire to learners in the selected schools. The questionnaire was to obtain information pertaining to learners' sociodemographic parameters, and their attitudes/practices vis-à-vis pesticides. The survey was beefed-up with interviews conducted with health personnel, heads of various institutions, learners and other resource persons; and direct field observations.

Statistical analysis of data was done on SPSS 16.0 and Microsoft Excel 2016 using descriptive and inferential statistics techniques. Descriptive statistics used were percentage indices, charts, mean and standard deviation while inferential statistics was the Kruskal-Wallis (H-test). The mean and standard deviation was used to show how learners' attitudes and behaviours vis-à-vis pesticides differ across different schools.

The Kruskal-Wallis test was run to test whether there was a significant variation in the reasons for learners' involvement in pesticides related activities across sampled schools. This H-Test has also been used in a similar survey to show variations when dealing with reasons affecting people's choices (Nkemleke \& Kuété, 2020).

The buffer zone was set at $1 \mathrm{~km}$. This is the maximum distance from the PHP to schools. This means that aerial spray of pesticides within this zone exposes the entire population to its harmful 145 effects. Other studies have equally considered buffer zones for pesticides spray from source areas 
146 to susceptible areas within 1 to $4 \mathrm{~km}$ (Frost \& Ware, 1970; Chester \& Ward, 1984; Hurley et al. 147 2014).

\section{$148 \quad$ 2.4. Variables used in the study}

149 This study made use of some dependent and independent variables (Table 2). These variables are 150 learner's age, incidence of pesticide contamination, category of pesticides, gender, suffer from 151 pesticides effects, live in proximity to PHP, spray during dry/windy weather conditions, training 152 in pesticides use, and interpret pesticides pictograms before use among others.

\section{Table 2: Variables used in the study}

\begin{tabular}{|c|c|}
\hline Variable & Description \\
\hline Learner's age & Continuous variable \\
\hline Category of pesticides use & Continuous variable \\
\hline Incidence of pesticide contamination & Continuous variable \\
\hline Suffer from pesticides effects & Dummy variable, takes the value of 1 if yes and, 0 if no \\
\hline Gender of respondents & Dummy variable, takes the value of 1 if male and, 0 if female \\
\hline Live in proximity to $\mathrm{PHP}$ & Dummy variable, takes the value of 1 if yes and, 0 if no \\
\hline Spray during dry/windy weather conditions & Dummy variable, takes the value of 1 if yes and, 0 if no \\
\hline Interpret pesticides pictograms before use & Dummy variable, takes the value of 1 if yes and, 0 if no \\
\hline Receive training in pesticides use & Dummy variable, takes the value of 1 if yes and, 0 if no \\
\hline Use individual protection clothing & Dummy variable, takes the value of 1 if yes and, 0 if no \\
\hline Eat while spraying pesticides & Dummy variable, takes the value of 1 if yes and, 0 if no \\
\hline Clean up after using pesticides & Dummy variable, takes the value of 1 if yes and, 0 if no \\
\hline Drink while spraying pesticides & Dummy variable, takes the value of 1 if yes and, 0 if no \\
\hline Effects of take home pesticides & Dummy variable, takes the value of 1 if yes and, 0 if no \\
\hline Medical attention when affected & Dummy variable, takes the value of 1 if yes and, 0 if no \\
\hline Harvest on treated farmland after spraying & Dummy variable, takes the value of 1 if yes and, 0 if no \\
\hline
\end{tabular}

$154 \quad$ Source: Field work, 2019

\section{Results and Discussion}

\subsection{Socio-demographics of learners}

The socio-demographics of the learners sampled are expressed statistically as gender, age, level of education and/or class, resident, and school. Learners were sampled in ten (10) schools. The first school among the ten was a government bilingual high school (60 learners sampled), school two was a private high school (60 learners sampled), school three was a government technical school (55 learners sampled) and school four was a government college (45 learners sampled), school five was a private college (60 learners sampled), school six was a government high school (30 learners sampled), school seven was a government college (65 learners sampled), school eight was a government college (40 learners sampled), school nine was a government high school (135 learners sampled) and school ten was a private college (50 learners sampled), (Table 3). 
172 Table 3: Socio-demographics of learners sampled

\begin{tabular}{llcc}
\hline Characteristics & Frequency & \% \\
\hline Gender & Male & 415 & 69.2 \\
& Female & 185 & 30.8 \\
& Total & $\mathbf{6 0 0}$ & $\mathbf{1 0 0}$ \\
Class & & \\
& Form 5 & 98 & 16.4 \\
& Lower Sixth & 233 & 38.8 \\
& Upper Sixth & 269 & 44.8 \\
& Total & $\mathbf{6 0 0}$ & $\mathbf{1 0 0}$ \\
Age & & & \\
& 10-15 Years & 12 & 2 \\
& 15-20 Years & 251 & 41.8 \\
& 20-25 Years & 285 & 47.5 \\
& 25-30 Years & 52 & 8.7 \\
Total & $\mathbf{6 0 0}$ & $\mathbf{1 0 0}$ \\
Reside near sprayed farms & & \\
& Yes & 390 & 65 \\
& No & 210 & 35 \\
Total & $\mathbf{6 0 0}$ & $\mathbf{1 0 0}$ \\
Type of learning institution & & \\
& Government school & 430 & 71.7 \\
& Private school & 170 & 28.3 \\
Total & $\mathbf{6 0 0}$ & $\mathbf{1 0 0}$ \\
\hline
\end{tabular}

Source: Field work, 2019

\subsection{Most used pesticides in the study area}

175 Small and large-scale farming activities in the study area use a variety of pesticides; some of which are not homologated or are banned products. For example, chlordecone ${ }^{2}$ said to have been banned for use worldwide, have been reportedly used by the PHP on its bananas ${ }^{3}$. Some of these banned chemicals used are the cause of many acute and chronic health problems perceived in the study area. Although insecticides, herbicides and fungicides are the different types of pesticides widely used, it should be noted that there are sub groups which equally have different names 181 (Table 4).

\footnotetext{
${ }^{2}$ Chlordecone is prohibited in Cameroon by decree No. 2011/2581/PM of August 23, 2011 Bearing regulation of harmful and/or dangerous chemicals

${ }^{3}$ Interview conducted by Transparency International Cameroon with the local population. Created by the American army, chlordecone is a pesticide made from very toxic chlorine, and suspected of being behind many cases of cancers.
} 
Table 4: Most used pesticides

\begin{tabular}{cccc}
\hline Pesticide & Product name & Toxicity class & Active ingredient \\
\hline \multirow{4}{*}{ Herbicides } & Glyphader & III & Glyphosate \\
\cline { 2 - 4 } & Gramoxone & & Paraquat 200g/l \\
\cline { 2 - 4 } & Supraxone & & Paraquat 200g/l \\
\cline { 2 - 4 } Insecticides & Roundup & II & Glyphosate \\
\cline { 2 - 4 } & Pyriforce & II & Chlorpyriphos-ethyl 600g/l; EC \\
\cline { 2 - 4 } & Capsidor & & Fipronil \\
\cline { 2 - 4 } & Imida & II & Imidaclopride \\
\cline { 2 - 4 } & Capt Fort 180 WP & II & Lamdacyphalothrine + acetamipride \\
\cline { 2 - 4 } & Chlordecone & II & \\
\hline Fungicides & Ridomil & III & Metalaxyl-M \\
\hline
\end{tabular}

Source: Field work, 2019

\subsection{Schools proximity to PHP}

188 One of the major concerns about pesticides use in agriculture is the potential for these chemicals to drift onto non-source points (neighbouring farms, and more importantly, into residential areas or school yards where students learn, work, and play). Pesticides can drift for about 400 to 800 metres away from the spraying areas.

192 Findings revealed that majority of secondary schools are located within 700 meters from the PHP in Loum and Njombe-Penja Subdivisions. Some of the schools are sited within 100 metres from the PHP while others are located somewhat less than 100 meters (Fig 2). For example schools like CETIC de Njombe, Collège Polyvalent, GBHS Njombe, CAMEL, GBHS Penja, GBHS Manengwassa and TISSERINS are all within the buffer zone with corresponding distances of $5 \mathrm{~m}$, $80 \mathrm{~m}, 115 \mathrm{~m}, 239 \mathrm{~m}, 591 \mathrm{~m}, 725 \mathrm{~m}$, and $802 \mathrm{~m}$ respectively. Learners in these schools are exposed to pesticides spray drift and more likely to be harmed by these chemicals than learners whose schools are further away from the PHP. Meanwhile on the contrary vein, only Lycée Technique de Loum, GSS Babong and SAR/SM Badjokip are situated out of the buffer zone with corresponding distances of $1.327 \mathrm{~km}, 9.963 \mathrm{~km}$ and $11.973 \mathrm{~km}$ respectively and learners here are less exposed to pesticides spray drifts and are unlikely to be harmed. 


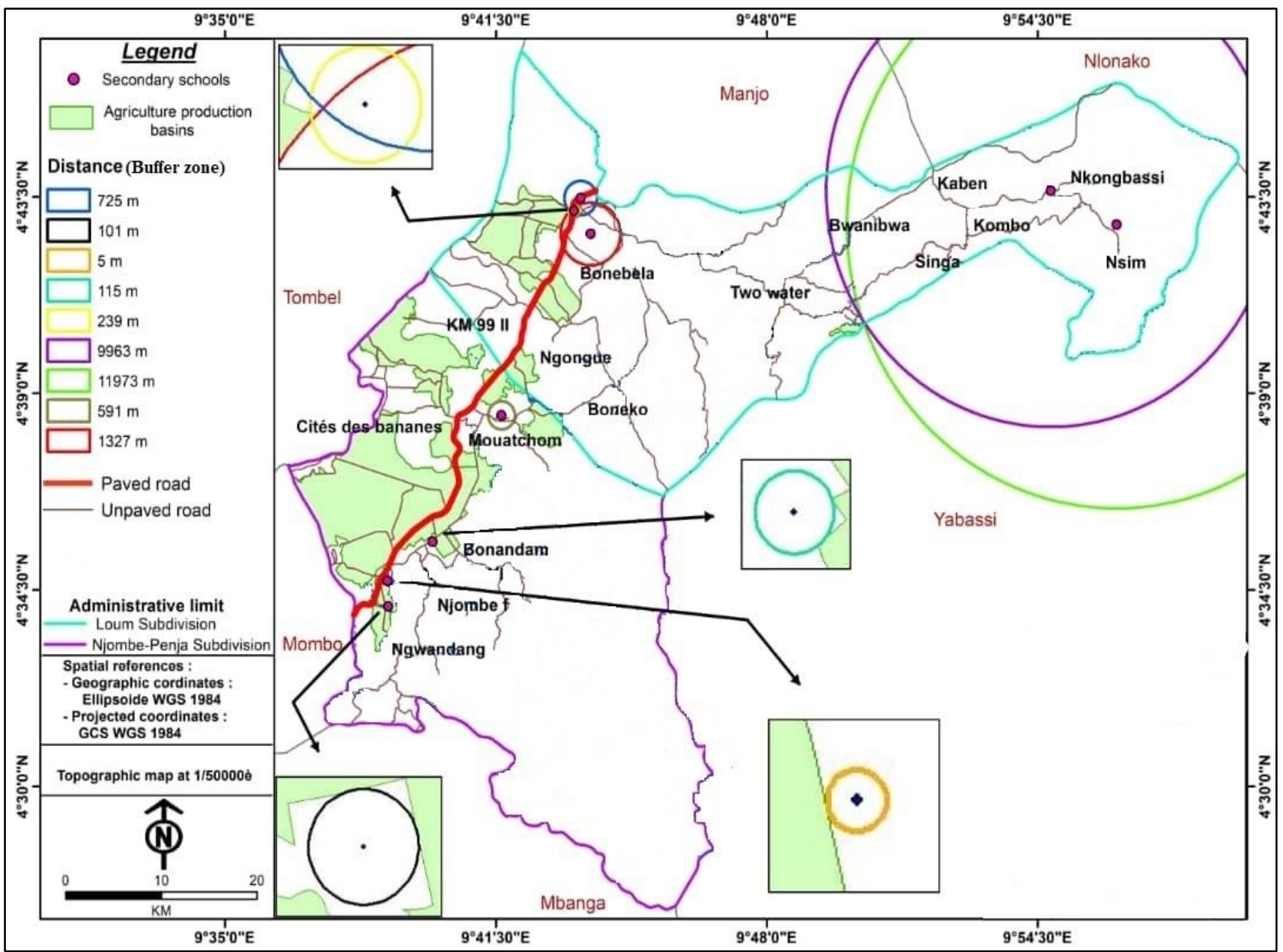

203

204

205

206

207

208

209

210

211

212

213

214

215

216

217

218

219

220

Source: National Institute of Cartography, 2018 and field work. Drawn by: Ernest Nkemleke

\section{Fig 2: Proximity of schools to the PHP}

This proximity of schools to the PHP exposes learners to pesticides infections borne by particles that drift from the PHP when aerial applications are done. Schools and/or residential proximity has equally been found to influence population exposure to agrichemicals by other studies (Ward et al. 2000; Lu et al. 2000; Fenske et al. 2000; Koch et al. 2002; Petchuay et al. 2006; Curwin et al., 2007; Panuwet et al. 2009; Morgan, 2012; Fenske et al. 2013; Hurley et al. 2014; and Rohitrattana, 2014; Nkemleke \& Kuété, 2020). These findings depict that residential and schools proximity to agricultural holdings where pesticides are sprayed expose the population and learners to pesticides harmful effects. The above-cited research findings lent credibility to the present findings and therefore giving a new insight to existing discourses on residential proximity and pesticides effects.

\subsection{Wind as the main driver of pesticides drift to schools}

Wind is one of the most significant factors that influences spray drift. Wind direction and speed are indisputable drivers of particles drift. Through these, wind blows particles from one area to another across the air. This factor influences drift over and above every other factor. When the wind speed increases, there is also a drastic increase in drift and vice versa. The amount of pesticide lost from the target area and the distance it moves both increases as wind velocity 
increases. However, severe drift effects can equally take place in a low wind velocity, especially under situations of temperature inversion. This study found that wind direction and speed influence the drift of pesticides to schools and resident as the prevailing wind blows towards the direction of schools and residential areas (Fig 3).

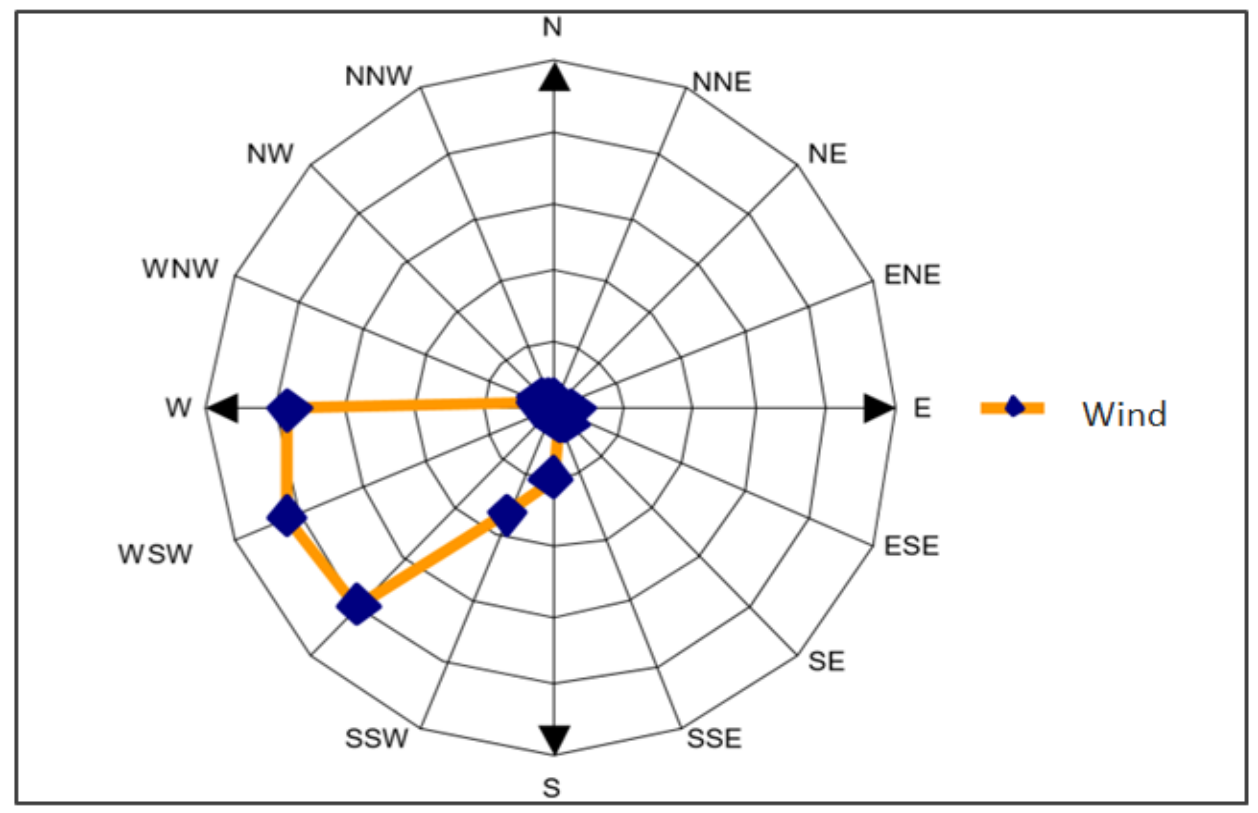

Source: Modified from Feumba, 2015

\section{Fig 3: Wind rose of Njombe-Penja with prevailing winds from WSW direction}

In Njombe-Penja and Loum Subdivisions, which is the centre of pesticides use by the PHP through aerial sprays, the prevailing wind blows in the South West direction. This wind comes into the hinterland from Atlantic Ocean. The influence of a mountain barrier (Mount Cameroon) at the western side of the Cameroon range causes the wind to deflect to the right. These winds also correspond to the sea breezes that are felt as from midday, reaching their maximum at 2 p.m. and continuing until 8 p.m., then decreasing until 10 p.m. These winds turn into a light breeze that lasts till 8a.m. These winds from the SW can raise hoods of cars in the estuary, because they reach $0.25 \mathrm{~m}$ in height and 4 to $5 \mathrm{~m}$ in wavelength and move at the speed of $30 \mathrm{~ms}^{-1}$. It is this wind which acts as the fastest means in drifting particles of pesticides in the air into off-target areas like school yards. The direction of the prevailing wind is WSW, (Fig 3). Schools proximity to the PHP means that particles are easily drifted from this plantation into inhabited areas. For example, Hanna \& Schaefer (2014), Graeme (2017), Baio et al. (2019), Desmarteau et al. (2019) have confirmed that air is one of the main pathways through which pesticides reach undesirable targets. The current research findings corroborate the above mentioned findings, thus, making a new insight in the existing literature. 
A comparative study between learners, who live and school closer to and those further away from the PHP, was conducted to determine learners' attitudes/practices vis-à-vis pesticides and proximity to agro-plantations.

\subsubsection{Comparison between learners' attitudes/practices vis-à-vis pesticides in Loum}

Learners, whose schools are further away from the PHP, were interviewed on some common pesticides related activities, (Table 5). Their responses were analysed with mean and standard deviation in order to determine the proportion of responses approving or disproving each claim.

Findings revealed that majority of learners in SAR/SM Badjokip which is located several kilometres away from the PHP do not live closer to sprayed farmlands ( $\bar{x}=1.00)$, though, some of the learners use pesticides on their personal farms $(\bar{x}=1.93)$, learners do not play on the farm when pesticides are sprayed $(\bar{x}=1.00)$, but they witness symptoms of pesticides effects $(\bar{x}=$ 1.56). Many household members witness the same symptoms $(\bar{x}=1.56)$, and the symptoms persist for a longer time before disappearing $(\bar{x}=1.51)$. Most learners eat during pesticides application $(\bar{x}=1.56)$, meanwhile others drink (alcohol in sachets, water) during pesticides application $(\bar{x}=1.56)$, (Table 5). All these broaden the rate of exposure to pesticides effects though; these learners live far away from the PHP.

In GSS Babong, learners live far off treated farmlands $(\bar{x}=1.00)$, but use pesticides on their own farms $(\bar{x}=1.92)$, play on the farm when small-scale application of pesticides is done $(\bar{x}=$ 1.42), but do not witness pesticides effects $(\bar{x}=1.12)$. Most of them eat and drink when using pesticides with mean values of $(\bar{x}=1.62)$ and $(\bar{x}=1.58)$ respectively (Table 5).

In Lycée Technique (L.T) de Loum which is also located further away from the PHP, learners live far off sprayed fields $(\bar{x}=1.00)$, but most of them manipulate and/or use pesticides $(\bar{x}=$ 2.00). Learners do not play on the farm when using pesticides $(\bar{x}=1.00)$, but they witness symptoms of pesticides effects $(\bar{x}=1.94)$. This could be as a result of contact via diverse means like transporting pesticides to the farm, mixing pesticides and spraying without individual protection kits. The same symptoms are also perceived on two or three other household members who manipulate pesticides $(\bar{x}=1.62)$, and the symptoms persist for a long duration $(\bar{x}=1.60)$ showing the severity of its effects. These symptoms could be due to the fact that most of them eat $(\bar{x}=1.60)$ and drink $(\bar{x}=1.60)$ during application of pesticides which further expose them to the harmful effects of these chemicals, (Table 5).

These findings prove that although learners in these schools live far away from sprayed farmlands (PHP), they also witness symptoms of pesticides effects. This is due to personal efforts from learners in attempts to alleviate poverty as they are involved in the manipulation of pesticides on their farms which makes them more vulnerable.

Meanwhile GBHS Manengwassa and CAMEL are the only sampled schools located close to PHP (Table 5). Findings among learners in GBHS Manengwassa revealed without contradiction that learners live closer to sprayed farmlands $(\bar{x}=1.75)$ and use pesticides $(\bar{x}=1.82)$. Also, most learners play around when pesticides are sprayed and they witness symptoms of pesticides effects with mean values of $(\bar{x}=1.32)$ and $(\bar{x}=1.80)$ respectively. With other household members infected by same symptoms $(\bar{x}=1.58)$, these symptoms persist for a long time before they disappear $(\bar{x}=1.55)$, sometimes after medical intervention for those who seek medical 
289 attention. Most of these learners eat $(\bar{x}=1.38)$ and drink $(\bar{x}=1.50)$ during pesticides 290 application, (Table 5).

291 In CAMEL, learners live closer to PHP $(\bar{x}=1.52)$ and use pesticides on their farms $(\bar{x}=2.00)$. 292 They do not play around when pesticides are sprayed $(\bar{x}=1.30)$ but all witness symptoms of 293 pesticides effects $(\bar{x}=1.80)$. This is because majority of these learners attend school located 294 few meters from the PHP where aerial applications are made. This increases the degree of 295 exposure to pesticides residues drifted to school yards. It should be recalled that these symptoms 296 are always witnessed on at least two or more household members $(\bar{x}=1.58)$ which show the 297 extent to which the population is vulnerable. Learners here do not eat while spraying pesticides 298 but do drink during this activity $(\bar{x}=1.37)$, (Table 5).

299 Following this analysis, learners who attend schools closer to PHP are more vulnerable to 300 pesticides effects than the ones further away from this PHP. In this same vein, learners who are 301 further away are equally affected by pesticides but this is due to contact during on-farm activities 302 where pesticides are used in a smaller scale or quantities. This implies that those who are further 303 away from the PHP are less vulnerable and consequently less affected by pesticides. 
Table 5: Learners' pesticides related activities in schools closer to and further away from the PHP in Loum Subdivision

\begin{tabular}{|c|c|c|c|c|c|c|c|c|c|c|c|c|c|c|c|}
\hline \multirow[b]{3}{*}{ Activities } & \multicolumn{6}{|c|}{ Schools located in proximity to the PHP } & \multicolumn{9}{|c|}{ Schools located further away from the PHP } \\
\hline & \multicolumn{3}{|c|}{$\begin{array}{c}\text { GBHS Manengwassa } \\
n=60\end{array}$} & \multicolumn{3}{|c|}{$\begin{array}{c}\text { CAMEL } \\
n=60\end{array}$} & \multicolumn{3}{|c|}{$\begin{array}{c}\text { L.T de Loum } \\
n=55\end{array}$} & \multicolumn{3}{|c|}{$\begin{array}{c}\begin{array}{c}\text { GSS Babong } \\
\mathrm{n}=40\end{array} \\
\end{array}$} & \multicolumn{3}{|c|}{$\underset{n=45}{\substack{\text { SAR/SM Badjokip } \\
\text { (S) }}}$} \\
\hline & $M$ & St.D & Remark & $M$ & St.D & Remark & $M$ & St.D & Remark & $M$ & St.D & Remark & $M$ & St.D & Remark \\
\hline $\begin{array}{l}\text { 1. Live closer to } \\
\text { sprayed farms }\end{array}$ & 1.75 & .439 & Accepted & 1.52 & .504 & Accepted & 1.00 & .504 & Rejected & 1.00 & .000 & Rejected & 1.00 & .252 & Rejected \\
\hline $\begin{array}{l}\text { 2. Use pesticides } \\
\text { personally }\end{array}$ & 1.82 & .390 & Accepted & 2.00 & .000 & Accepted & 2.00 & .000 & Accepted & 1.92 & .267 & Accepted & 1.93 & .506 & Accepted \\
\hline $\begin{array}{l}\text { 3. Play around when } \\
\text { pesticides are sprayed }\end{array}$ & 1.32 & .469 & Accepted & 1.30 & .462 & Rejected & 1.00 & .000 & Rejected & 1.42 & .501 & Accepted & 1.00 & .000 & Rejected \\
\hline $\begin{array}{l}\text { 4. Witness pesticide } \\
\text { health symptoms }\end{array}$ & 1.80 & .403 & Accepted & 1.80 & .403 & Accepted & 1.92 & .267 & Accepted & 1.12 & .335 & Rejected & 1.56 & .503 & Accepted \\
\hline $\begin{array}{l}\text { 5. Same symptoms } \\
\text { perceived by a family } \\
\text { member }\end{array}$ & 1.58 & .497 & Accepted & 1.58 & .497 & Accepted & 1.62 & .490 & Accepted & 1.15 & .362 & Rejected & 1.56 & .503 & Accepted \\
\hline 6. Symptoms persist & 1.55 & .502 & Accepted & 1.50 & .504 & Accepted & 1.60 & .496 & Accepted & 1.12 & .335 & Rejected & 1.51 & .506 & Accepted \\
\hline $\begin{array}{l}\text { 7. Eat during } \\
\text { pesticides spray }\end{array}$ & 1.38 & .490 & Accepted & 1.30 & .462 & Rejected & 1.60 & .496 & Accepted & 1.62 & .490 & Accepted & 1.51 & .506 & Accepted \\
\hline $\begin{array}{l}\text { 8. Drink during } \\
\text { pesticides spray }\end{array}$ & 1.50 & .504 & Accepted & 1.37 & .486 & Accepted & 1.60 & .496 & Accepted & 1.58 & .501 & Accepted & 1.51 & .506 & Accepted \\
\hline
\end{tabular}

Source: Calculations based on field data, 2019.

N.B: $M=$ Mean; St.D= Standard Deviation. GBHS Manengwassa and CAMEL *(Rejected $(\bar{x} \leq 1.3)$, Accepted $(\bar{x}>1.3))$. SAR/SM Badjokip

$*($ Rejected $(\bar{x} \leq 1.23)$, Accepted $(\bar{x}>1.23))$. GSS Babong and L.T de Loum * $(\operatorname{Rejected}(\bar{x} \leq 1.2)$, Accepted $(\bar{x}>1.2))$ 


\subsubsection{Comparison between learners' attitudes/practices vis-à-vis pesticides in Njombe- Penja}

Findings revealed that learners in GBHS Njombe live closer to the PHP $(\bar{x}=1.68)$, and some use pesticides on their farmlands $(\bar{x}=1.72)$. Thus, this shows the degree of vulnerability to pesticides. These learners do not play around $(\bar{x}=1.43)$ when pesticides are used yet they witness symptoms of pesticides effects $(\bar{x}=1.79)$. This shows that pesticides are drifted and deposited in school where learners get in contact with. Also, they eat $(\bar{x}=1.78)$ and drink $(\bar{x}=$ 1.86) when aerial sprays of pesticides are done, (Table 6).

In TISSERINS, most learners do not live closer to the PHP $(\bar{x}=1.52)$ but use pesticides on their individual farmlands $(\bar{x}=2.00)$. They move around during aerial spray $(\bar{x}=1.85)$ and perceive symptoms of pesticides effects $(\bar{x}=2.00)$, although the same symptoms are not perceived by other learners $(\bar{x}=1.55)$. Learners in these school do not eat $(\bar{x}=1.38)$ during pesticides spray but they drink $(\bar{x}=1.92)$. With regards to GBHS Njombe, learners live closer to PHP $(\bar{x}=$ $1.67)$ and use pesticides on their personal farms $(\bar{x}=2.00)$. They do not play around when aerial spraying is done, perceive no health symptoms, do not eat and drink during pesticides application with corresponding mean values of $(\bar{x}=1.00),(\bar{x}=1.60),(\bar{x}=1.30)$ and $(\bar{x}=$ 1.33) respectively, (Table 6). This could be due to the fact that learners in this school are more cautious than their peers in other schools.

With regards to schools closer to the PHP (CETIC de Njombe and College Polyvalent), most learners live closer to PHP with respective mean values of $(\bar{x}=1.54)$ and $(\bar{x}=1.58)$. Also, in CETIC de Njombe, some learners use pesticides to spray crops $(\bar{x}=1.80)$ likewise in College Polyvalent $(\bar{x}=1.96)$. They also move around $(\bar{x}=1.42)$ when aerial sprays of pesticides by the PHP helicopter are done likewise in College Polyvalent $(\bar{x}=1.38)$. Learners are exposed to pesticides effects in these localities, yet in CETIC de Njombe they perceive no symptom of pesticides effects $(\bar{x}=1.18)$, but symptoms were reported among learners in College Polyvalent $(\bar{x}=1.76)$. These symptoms are rare among learners in CETIC de Njombe, though they always eat during pesticides spraying $(\bar{x}=1.42)$ but do not drink $(\bar{x}=1.32)$, (Table 6). Meanwhile in College Polyvalent, same symptoms were also perceived on other household members $(\bar{x}=$ 1.72), but do not persist for a long duration $(\bar{x}=1.76)$. In this same light, learners do not eat when pesticides are sprayed $(\bar{x}=1.02)$, but they $\operatorname{drink}(\bar{x}=1.48)$, (Table 6$)$.

Following these results, it is noticed that almost all learners live closer to PHP in Njombe-Penja Subdivision. It is equally observed that, symptoms of pesticides health effects are common among learners who attend school closer to PHP than those who are further apart albeit not without symptoms. The symptoms reported among the latter are due to exposure during individual on-farm activities and the severity of these symptoms is not much as compare to those closer to the PHP where aerial sprays are done (approximately 50 sprays per month). This further increases the odds of being affected by pesticides. 
Table 6: Learners' pesticides related activities in schools closer to and further away from PHP in Njombe-Penja

\begin{tabular}{|c|c|c|c|c|c|c|c|c|c|c|c|c|c|c|c|}
\hline \multirow[b]{3}{*}{ Activities } & \multicolumn{9}{|c|}{ School located in proximity to the PHP } & \multicolumn{6}{|c|}{ School located further away from the PHP } \\
\hline & \multicolumn{3}{|c|}{$\begin{array}{l}\text { GBHS Njombe } \\
\qquad n=135\end{array}$} & \multicolumn{3}{|c|}{$\begin{array}{c}\text { TISSERINS } \\
\mathbf{n}=60\end{array}$} & \multicolumn{3}{|c|}{$\begin{array}{c}\text { GBHS Penja } \\
\mathbf{n}=\mathbf{3 0}\end{array}$} & \multicolumn{3}{|c|}{$\begin{array}{c}\text { CETIC de } \\
\begin{array}{c}\text { Njombe-Penja } \\
n=65\end{array} \\
\end{array}$} & \multicolumn{3}{|c|}{$\begin{array}{c}\text { Collège Polyvalent } \\
\mathbf{n}=\mathbf{5 0}\end{array}$} \\
\hline & $M$ & St.D & Remark & $M$ & St.D & Remark & $M$ & St.D & Remark & $M$ & St.D & Remark & $M$ & St.D & Remark \\
\hline $\begin{array}{l}\text { 1. Live closer to } \\
\text { sprayed farms }\end{array}$ & 1.69 & .496 & Accepted & 1.52 & .504 & Accepted & 1.67 & .479 & Accepted & 1.54 & .502 & Accepted & 1.58 & .499 & Accepted \\
\hline $\begin{array}{l}\text { 2. Use } \\
\text { pesticides }\end{array}$ & 1.72 & .451 & Accepted & 2.00 & .000 & Accepted & 2.00 & .000 & Accepted & 1.80 & .403 & Accepted & 1.96 & .198 & Accepted \\
\hline $\begin{array}{l}\text { 3. Play around } \\
\text { when pesticides } \\
\text { are used }\end{array}$ & 1.43 & .497 & Rejected & 1.85 & .360 & Accepted & 1.00 & .000 & Rejected & 1.42 & .497 & Accepted & 1.38 & .490 & Accepted \\
\hline $\begin{array}{l}\text { 4. Witness } \\
\text { pesticide health } \\
\text { symptoms }\end{array}$ & 1.79 & .407 & Accepted & 2.00 & .000 & Accepted & 1.60 & .498 & Accepted & 1.18 & .391 & Rejected & 1.76 & .431 & Accepted \\
\hline $\begin{array}{l}\text { 5. Same } \\
\text { symptoms } \\
\text { perceived by a } \\
\text { family member }\end{array}$ & 1.14 & .349 & Rejected & 1.55 & .502 & Accepted & 1.40 & .498 & Accepted & 1.15 & .497 & Rejected & 1.72 & .454 & Accepted \\
\hline $\begin{array}{l}\text { 6. Symptoms } \\
\text { persist }\end{array}$ & 1.86 & .349 & Accepted & 1.93 & .252 & Accepted & 1.27 & .450 & Accepted & 1.57 & .499 & Accepted & 1.76 & .431 & Accepted \\
\hline $\begin{array}{l}\text { 7. Eat during } \\
\text { pesticides spray }\end{array}$ & 1.78 & .417 & Accepted & 1.38 & .490 & Accepted & 1.30 & .466 & Accepted & 1.42 & .497 & Accepted & 1.02 & .141 & Rejected \\
\hline $\begin{array}{l}\text { 8. Drink during } \\
\text { pesticides spray }\end{array}$ & 1.86 & .349 & Accepted & 1.92 & .279 & Accepted & 1.33 & .479 & Accepted & 1.32 & .471 & Rejected & 1.48 & .505 & Accepted \\
\hline
\end{tabular}

Source: Calculations based on field data, 2018.

N.B: $M=$ Mean; St.D $=$ Standard Deviation. GBHS Njombe $*($ Rejected $(\bar{x} \leq 1.68)$, Accepted $(\bar{x}>1.68))$. TISSERINS $*($ Rejected $(\bar{x} \leq 1.3)$, Accepted $(\bar{x}>1.3))$. GBHS Penja $*(\operatorname{Rejected}(\bar{x} \leq 1.15)$, Accepted $(\bar{x}>1.15))$. CETIC de Njombe $*(\operatorname{Rejected}(\bar{x} \leq 1.33)$, (Accepted $(\bar{x}>1.33))$. Collège Polyvalent $*($ Rejected $(\bar{x} \leq 1.25)$, (Accepted $(\bar{x}>1.25))$. 


\subsection{Symptoms of pesticide harmful effects among learners in various schools}

Pesticides related health symptoms manifest on the body when someone is exposed to it. These health effects are short and long term. Some symptoms manifest within a shorter period of time, say within 24 hours after exposure while others take a longer time period to manifest. Students from all sampled schools who handle pesticides reported some symptoms within a time period of 24 hours while others reported symptoms few hours/days after spraying (Fig4).

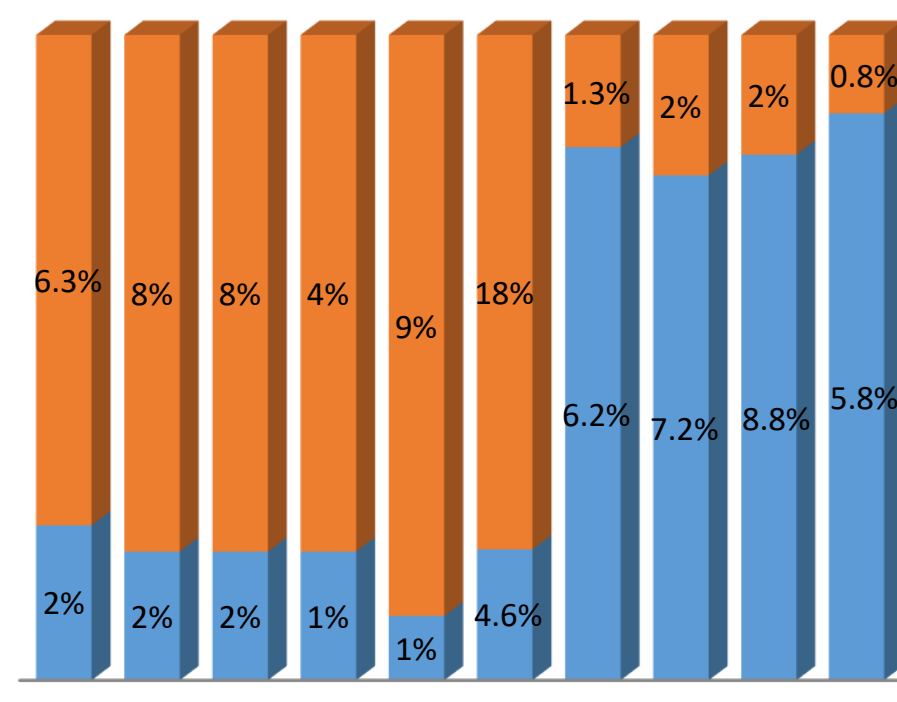

- Symptoms of pesticides effects

no symptoms of pesticides effects

Source: Field work, 2019

\section{Fig. 4: Symptoms of pesticide harmful effects across schools}

Fig. 4 clearly shows that learners in schools closer to the PHP witness pesticides related health effects than those in schools further away. Schools closer to the PHP like College Polyvalent, CAMEL, GBHS Manengwassa, GBHS Penja, TISSERINS and GBHS Njombe registered the highest number of health symptoms or effects with $6.3 \%, 8 \%, 8 \%, 4 \%, 10 \%$ and $18 \%$ respectively (Figure). Meanwhile schools further away from PHP registered fewer numbers of pesticides related health effects. SAR/SM Badjokip, Lycée Technique de Loum, CETIC de Njombe-Penja and GSS Babong are among this category with over 6\%, 7\%, 8\% and 5\% respectively. It should be noted here that students who show symptoms of pesticides effects in schools further away from the PHP get into contact with pesticides during on-farm activities.

\subsection{Leaners' involvement in handling pesticides out of school}

In ranking the reasons for learners' involvement in pesticides use out of school and to see if these reasons differ across sampled schools, the Kruskal-Wallis (H-test) was used (Table 7). Based on the Mean Ranks of the Kruskal-Wallis test it was found that among learners who are involved in pesticides related activities out of school, learners in Lycée Technique de Loum (mean rank = 
391.97), GSS Babong (mean rank = 406.31), and Collège Polyvalent Penja (mean rank = 434.55) are involved in pesticides related activities because of a plethora of reasons (spraying their parents' farmlands, their personal farmlands, spraying for remuneration, own chemical shops, and transport or distribute pesticides) than their counterparts in GBHS Penja (mean rank $=283.80$ ), GBHS Manengwassa (mean rank = 239.22), CAMEL (mean rank = 287.39), SAR/SM Badjokip $($ mean rank $=268.44)$, TISSERINS (mean rank $=189.27)$, CETIC de Njombe (mean rank = 271.68), and GBHS Njombe (mean rank = 293.00), who use pesticides only on their parents' farmlands (Table 7). In this same vein, the Kruskal-Wallis statistic indicated that there was a statistically significant difference among the reasons why learners are more involved in pesticides related activities across different schools $\left(X^{2}=104.532, \mathrm{p}<0.05\right)$. This further indicates that the reasons why learners carry out pesticides related activities vary significantly from one school to another.

Table 7: Ranking learners' reasons for using pesticide across school

\begin{tabular}{lccccc}
\hline School & $\begin{array}{c}\text { Frequency } \\
(\mathbf{n})\end{array}$ & \% & Mean Rank & $\boldsymbol{X}^{\mathbf{2}}$ & p-level \\
\hline GBHS Manengwassa & 60 & 10 & 239.22 & 104.532 & $0.000^{*}$ \\
CAMEL & 60 & 10 & 287.39 & & \\
Lycée Technique de Loum & 55 & 9.2 & 391.97 & & \\
SAR/SM Badjokip & 45 & 7.5 & 268.44 & & \\
TISSERINS Njombe & 60 & 10 & 189.27 & \\
GBHS Penja & 30 & 5 & 283.80 & \\
CETIC de Njombe & 65 & 10.8 & 271.68 & & \\
GSS Babong & 40 & 6.7 & 406.31 & & \\
GBHS Njombe & 135 & 22.5 & 293.00 & & \\
Collège Polyvalent Penja & 50 & 8.3 & 434.55 & & \\
\hline
\end{tabular}

*Significant at 0.05 probability level

\section{8}

\subsection{Types of symptoms/illnesses among learners according to age group}

A study conducted by Antle \& Pingali (1994) depicts that "scientific confirmed pesticide related acute illnesses are headaches, stomach pains, vomiting, skin rashes, respiratory problems, eye irritations, sneezing, seizures, and coma". Similarly, according to the US EPA Office of Research and Development's Asthma Research Strategy, "some pesticides have been linked to long term health problems, including: Cancer; asthma; leukemia; birth defects; endocrine disruption; neurological disorders and immune system deficiencies".

The PHP is the highest user of pesticides in this area. These plantations carry out about 50 aerial sprays per month. Given that little or no effort has been done to minimise the environmental effects of these pesticides, residents closer to these plantation tend to bear the greatest brunt. Data sourced from health personnel show that pesticides related symptoms and illnesses are common among school going children (Table 8).

Findings revealed that pesticides related health symptoms and illnesses were common among 392 youths aged between 20-25 years (143 cases) and between ages of 25-30 years (87 cases). Meanwhile these symptoms/illnesses were few among youth between the ages 10-15 and 15-20 
393 (with 58 and 61 cases respectively) as compared to the former. This therefore, implies that older 394 learners or students are exposed to agropesticides in this area than their younger counterparts.

395 Table 8: Types of pesticide related symptoms/illnesses amongst school-aged population

\begin{tabular}{|c|c|c|}
\hline Age group & Illness/symptom & No. of cases \\
\hline \multirow{7}{*}{ 10-15 Years } & Diarrhea & 4 \\
\hline & Blurred double vision & 8 \\
\hline & Testicular cancer & 2 \\
\hline & Dry cough & 8 \\
\hline & Bone cancer & 5 \\
\hline & Bronchitis & 5 \\
\hline & Abdominal pain/fever & 26 \\
\hline \multirow[t]{4}{*}{ Total } & & 58 \\
\hline & Direct intoxication by chemicals & 2 \\
\hline & Bilious & 5 \\
\hline & Diarrhea & 4 \\
\hline \multirow[t]{4}{*}{$15-20$ Years } & Itches & 2 \\
\hline & Respiratory problem & 31 \\
\hline & Blurred double vision & 13 \\
\hline & Bronchitis & 4 \\
\hline \multirow[t]{4}{*}{ Total } & & 61 \\
\hline & Anorexia & 6 \\
\hline & Leukemia & 31 \\
\hline & Asthenia & 13 \\
\hline \multirow[t]{5}{*}{ 20-25 Years } & Memory loss & 5 \\
\hline & Dry cough & 9 \\
\hline & Diarrhea & 6 \\
\hline & Blurred double vision & 18 \\
\hline & Abdominal pain/fever & 55 \\
\hline \multirow[t]{4}{*}{ Total } & & 143 \\
\hline & Leukemia & 35 \\
\hline & Asthma & 8 \\
\hline & Asthenia & 12 \\
\hline \multirow[t]{5}{*}{ 25-30 Years } & Severe anemia & 10 \\
\hline & Abdominal pain/fever & 6 \\
\hline & Respiratory problem & 5 \\
\hline & Itches & 1 \\
\hline & Diarrhea & 10 \\
\hline Total & & 87 \\
\hline
\end{tabular}

Source: District hospital Loum and Malt hospital Njombe, 2019

397 Other studies have equally reported the aforementioned symptoms and illnesses related to the use 398 of pesticides (Maroni \& Fait, 1993; Dich et al. 1997; Zahm et al. 1997; Kirkhorn \& Schenker, 399 2002; Richter \& Chlamtac, 2002 and Alavanja et al. 2004). It must be said that, these symptoms 400 and illnesses were found on school going population who are only vulnerable to pesticides 401 harmful effects; due to the fact that schools are located closer to agro-industrial plantations in the 402 study area. However, other studies (Tetang \& Foka, 2008; Manfo, 2010; Kenko et al. 2017 and 


\section{$434 \quad$ Funding}

435 No external funding was received.

\section{Data availability}

437 The authors agreed that data generated in the course of this study is included in this article and its 438 supplementary information files.

\section{Compliance with ethical standards}

440 Conflict of interests

441 The authors declared no conflict of interests.

\section{Ethics approval}

443 The authors stated that ethical standards were respected. 
The authors confirm the volunteer's declaration of consent.

\section{Consent to publish}

The authors confirm the volunteer's consent for publication. The data on the incidence of contamination obtained in different health establishments in the Mungo Division and the maps generated from the National Institute of Cartography Geo database in Yaounde have be given permission to be published.

\section{References}

Alavanja, M. C., Hoppin, J., \& Kamel, F. Health effects of chronic pesticide exposure: cancer and neurotoxicity. Annual Review of Public Health, (2004): 25, 155-197.

Antle J.M \& Pingali P.L. Pesticides, Productivity, and Farmer Health: A Philippine Case Study. Amer. J. Agric. Econ., (1994): 76: 418-430.

Baetens, K., Ho, Q.T., Nuyttens, D., De Schampheleire, M., Melese Endalew, A., Hertog, L.A.T.M., Nicolai, B., Ramon, H., Verboven, P. A validated 2-D diffusioneadvection model for prediction of drift from ground boom sprayers. Atmos. Environ. (2009): 43.

Balsari, P., M. Grella, P. Marucco, F. Matta, et A. Miranda-Fuentes. Assessing the influence of air speed and liquid flow rate on the droplet size and homogeneity in pneumatic spraying. Pest Manag. Sci., (2019): 75, 366-379.

Baio F.H.R., Antuniassi U.R., Castilho B.R., Teodoro P.E., \& Silva E.E.d. Factors affecting aerial spray drift in the Brazilian Cerrado. PLoS ONE , (2019): 14(2): 212-289.

Brody, J.G., Vorhees, D.J., Melly, S.J., Swedis, S.R., Drivas, P.J., \& Rudel, R.A. Using GIS and historical records to reconstruct residential exposure to large-scale pesticide application. Journal of Exposure Science and Environmental Epidemiology, (2002): 12(1), 64-80.

Chester G, \& Ward RJ. Occupational exposure and drift hazard during aerial application of paraquat to cotton. Environ Contamin Toxicol, (1984):13:551-563.

Curwin B.D., Misty J.H., Wayne T.S., Striley C., Reynolds S.J., Alavanja D.H., \& Kromhout H. Urinary pesticide concentrations among children, mothers and fathers living in farm and non-farm households in Iowa. Ann Occup Hyg, (2007): 51(1): 53-65. doi:10.1093/annhyg/mel062

De Jong, A., Michielson, J., Stallinga, H., Van De Zande, J. Effect of sprayer boom height on spray drift. Medelingen Univ. Gent , (2000): 65 (2b), 919-930.

Desmarteau D.A, Ritter A.M, Hendley P, \& Guevara M. W. Impact of Wind Speed and Direction and Key Meteorological Parameters on Potential Pesticide Drift Mass Loadings from Sequential Aerial Applications . Integr Environ Assess Manag, (2019): 1-14.

Dich J, Zahm SH, Hanberg A. Pesticides and cancer. Cancer Causes Control, (1997): 8: 420-43.

FAO and WHO. The International Code of Conduct on Pesticide Management. E-ISBN 978-925-108549-3. (2014): Available online: http://www.fao.org/fileadmin/templates/agphome/documents/Pests_Pesticides/Code/COD E_2014Sep_ENG.pdf (accessed on 23 April 2016). 
Fenske R.K, Lu C., Nancy J.S., Loewenherz C., Touchstone J., Moate F.T., Allen E.H., \& Kissel J.C. Strategies for assessing children's organophosphorus pesticides exposures in agricultural communities. Journal of Exposure Analysis and Environment 10, (2000): 662-671.

Fenske R.A., Lu C., Negrete M., \& Galvin K. Breaking the Take Home Pesticide Exposure Pathway for Agricultural Families: Workplace Predictors of Residential Contamination. Am J Ind Med; (2013): 56(9), 1063-1071.

Feumba R. Hydrologies et évaluation de la vulnérabilité des nappes dans le bassin versant de Besseke (Douala, Cameroun). Thèse de doctorat/Ph.D. en science de la terre. Université de Yaoundé 1. 254p, 2015.

Franklin, C.A., \& Worgan, J. P. (eds.). Occupational and residential exposure assessment for pesticides. . Chichester, UK: John Wiley \& Sons, Ltd. (2005).

Frost KR, \& Ware GW. Pesticide drift from aerial and ground applications. Agric Eng, (1970): 51:460-467.

Gil, Y., \& Sinfort, C. Emission of pesticides to the air during sprayer application: a bibliographic review. Atmos. Environ, (2005): 39 (28), 5183-5193.

Graeme T. Weather Essentials for Pesticide Application. GRDC Project Code: TEP00001 General meteorology for pesticide application booklet. KINGSTON ACT 2604, (2017).

Ghosh, S., \& Hunt, J. Spray jets in a cross-flow. J. Fluid Mech, (1998): 365, 109-136.

Hanna M, \& Schaefer K. Factors affecting pesticide drift. Iowa State University, (2014).

Hurley J.A., T.A. Green, D.H. Gouge, Z.T. Bruns, T. Stock, L. Braband, K. Murray, C. Westinghouse, S.T. Ratcliffe, D. Pehlman, \& L. Crane. Regulating Pesticide Use in United States Schools". American Entomologist, (2014): Volume 60, Number 2. Pp. 106114

Koch D., Lu C., Jennifer F-A., Jolley L., and Fenske R.A. Temporal Association of Children's Pesticide Exposure and Agricultural Spraying: Report of a Longitudinal Biological Monitoring Study. Environ Health Perspect 110, (2002): 829-833.

Kirkhorn SR, Schenker MB. Current health effects of agricultural work: respiratory disease, cancer, reproductive effects, musculoskeletal injuries, and pesticide-related illnesses. $J$ Agric Saf Health, (2002): 8: 199-214.

Kenko N. D, Asanga B. F., Ngameni T, N, and Mbida M. Environmental and Human Health Assessment in Relation to Pesticide Use by Local Farmers and the Cameroon Development Corporation (CDC), Fako Division, South-West Cameroon. European Scientific Journal, (2017): Vol.13, No.21 pp: 1857 - 7881. URL:http://dx.doi.org/10.19044/esj.2017.v13n21p454

Lu, C., Fenske, R.A., Simcox, N.J., \& Kalman, D. Pesticide exposure of children in an agricultural community: Evidence of household proximity to farmland and take home exposure pathways. Environmental Research, (2000): 84, 290-302.

Manfo, F.P.T., Moundipa, P.F., Déchaud, H., Tchana, A.N., Nantia, E.A., Zabot, M.T. \& Pugeat, M. Effect of agropesticides use on male reproductive function: a study on farmers in Djutitsa (Cameroon). Env. Toxicol, (2010): 1-10. DOI 10.1002:1-10. 
Maroni M. \& Fait A. Health effects in man from long-term exposure to pesticides: a review of the 1975-1991 literature. Toxicology, (1993): 78: 1-180.

Morgan MK. Children's exposures to pyrethroid insecticides at home: a review of data collected in published exposure measurement studies conducted in the United States." Int J Environ Res Public Health, (2012): 9(8):2964-2985.

Miller, P.C.H. Spray drift and its measurement. Dans Application Technology for Crop Protection, de G.A., Hislop, E.C. (Eds.) Matthews. E.C., CABI, (1993).

Miller, P.C.H., Smith, R. The effects of forward speed on the drift from boom sprayers. The 1997 Brighton Crop Protection Conference-weeds, (1997): 399-406.

Miller, P.C.H., \& Butler Ellis, M.C. Effects of formulation on spray nozzleperformance for applications from ground-based boom sprayers. Crop Prot., (2000): 19, 609-615.

Muir Dcg, Teixeira C, Wania F. Empirical and modeling evidence of regional atmospheric transport of current-use pesticides. Environ Toxico Chem, (2004): 23:2421-2432.

Nkemleke E.E. \& Kuété M. An Assessment of School Going Population Exposure Pathways to Agropesticide in the Mungo Corridor of Cameroon, European Scientific Journal, ESJ (2020): Vol.16, No.26: 123. URL:http://dx.doi.org/10.19044/esj.2020.v16n26p123

Nkemleke E.E. Assessing Small-Scale Farmers' Attitudes, Practices and Vulnerability to Pesticides Use in Market Gardening Crops in M'muockngie (South Western Cameroon). J Adv Educ Philos, (2020): 4(6): 295-305. DOI: 10.36348/jaep.2020.v04i06.010.

Nuckols, J.R., Ward, M.H., \& Jarup, L. Using geographic information systems for exposure assessment in environmental epidemiology studies. Environmental Health Perspectives, (2004): 112(9), 1007-1015.

Nuyttens, D., De Schampheleire, M., Baetens, K., Sonek, B. The influence of operator controlled variables on spray drift from field crop sprayers. Trans. ASABE, (2007): 50 (4), 11291140.

Panuwet P., Prapamontol T., Chantara S., \& Barr D.B. Urinary pesticide metabolites in school students from northern Thailand. Int J Hyg Environ Health, (2009): 212(3): 288-297.

Petchuay C., Visuthismajarn P., Vitayavirasak B., Hore P., \& Robson M.G. Biological monitoring of organophosphate pesticides in preschool children in an agricultural community in Thailand. Int J Occup Environ Health, (2006): 12(2):134-141.

Pouokam G.B., Lemnyuy W.A., Ndikontar A.S., \& Sidatt M.A Pilot Study in Cameroon to Understand Safe Uses of Pesticides in Agriculture, Risk Factors for Farmers' Exposure and Management of Accidental Cases. Toxics, (2017): 5, 30; 15p. Doi: 10.3390/toxics5040030

Rohitrattana. Pyrethroid insecticide exposure in school-aged children living in rice and aqua cultural farming regions of Thailand. Risk Management and Healthcare Policy, (2014): 7 211-217.

Richter E.D. \& Chlamtac N. Ames, pesticides and cancer revisted. J Occup Environ Health, (2002): 8: 63-72. 
Tetang T.J. \& Foka G. Utilisation des pesticides dans la zone agricole du Moungo- Evaluation de l'impact sur 1'environnement, la santé des populations, et solutions envisageables : cas de la localité de Njombé dans 1'arrondissement de Njombé-Penja. Pesticide Bull, (2008): 2:12-16.

US, EPA. Agrichemicals food quality protection Act-Children and consumers. (2007): http://www.epa.gov/agriculture/factsheets/epa-305-f-00-005aghtml.Date accessed11/2011.

Van de Zande, J., Parkin, C., Gilbert, A. Application technologies. Dans Optimizing Pesticide Use, de M. (Ed.) Wilson, pp. 23-44. UK: Wiley, Chichester. (2003).

Ward, M.H., Nuckols, J., Weigel, S.J., Maxwell, S.K., Cantor, K.P., \& Miller, R.S. Identifying populations potentially exposed to agricultural pesticides using remote sensing and a geographic information system. Environmental Health Perspect, (2000): 108(1), 5-12.

Womac, A., Etheridge, R., Seibert, A., Hogan, D., Ray, S. Sprayer speed and venturi nozzle effects on broadcast application uniformity. Trans. ASAE, (2000): 44, 1437-1444.

Yi, C. Momentum transfer within canopies. J. Appl. Meteorol. Climatol, (2008): 47, 262-275.

Zahm SH, Ward MH, Blair A. Pesticides and cancer. Occup Med, (1997) 12: 269-289. 


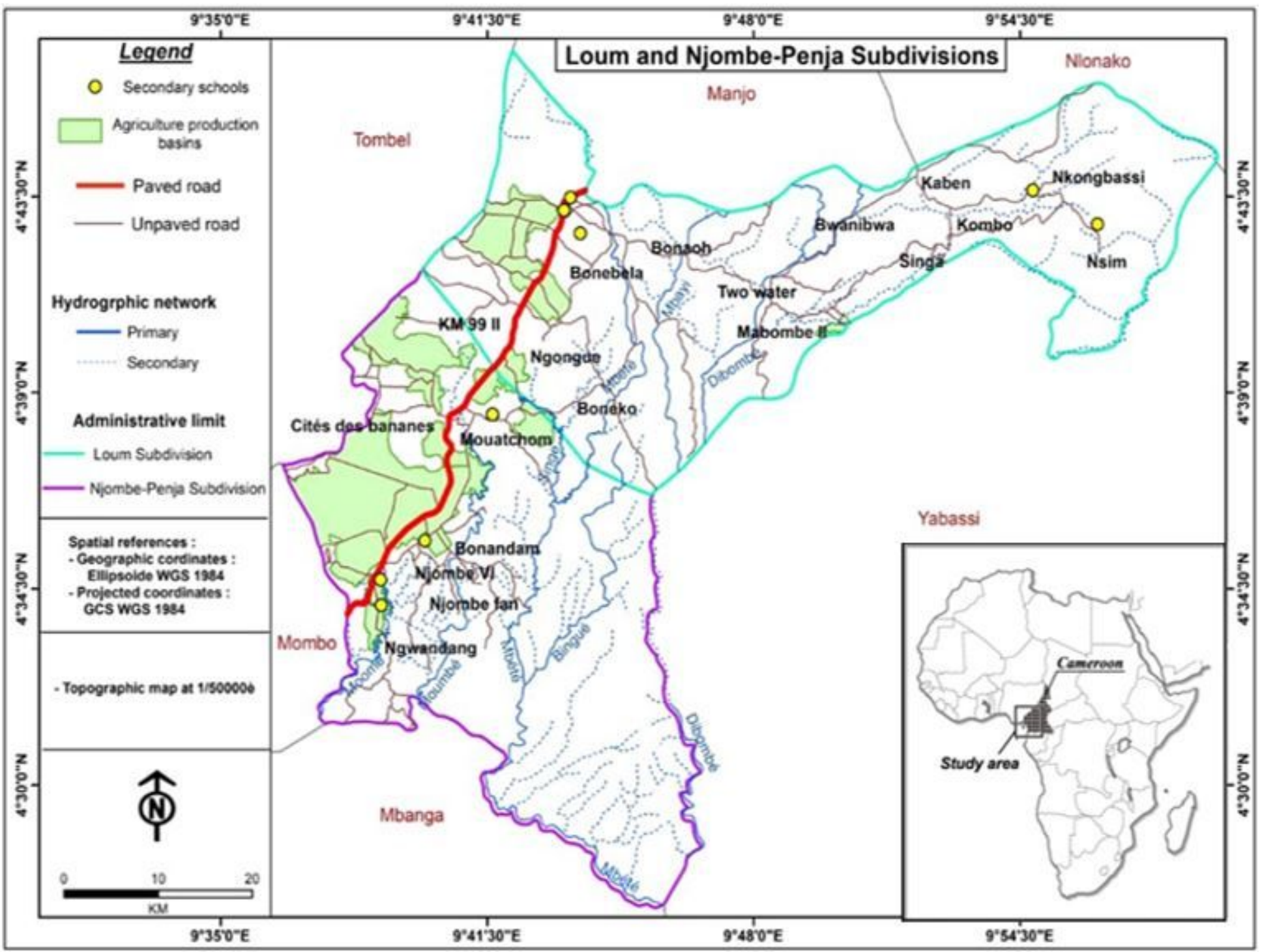

\section{Figure 1}

Map showing Loum and Njombe-Penja in the Mungo Division. Note: The designations employed and the presentation of the material on this map do not imply the expression of any opinion whatsoever on the part of Research Square concerning the legal status of any country, territory, city or area or of its authorities, or concerning the delimitation of its frontiers or boundaries. This map has been provided by the authors. 


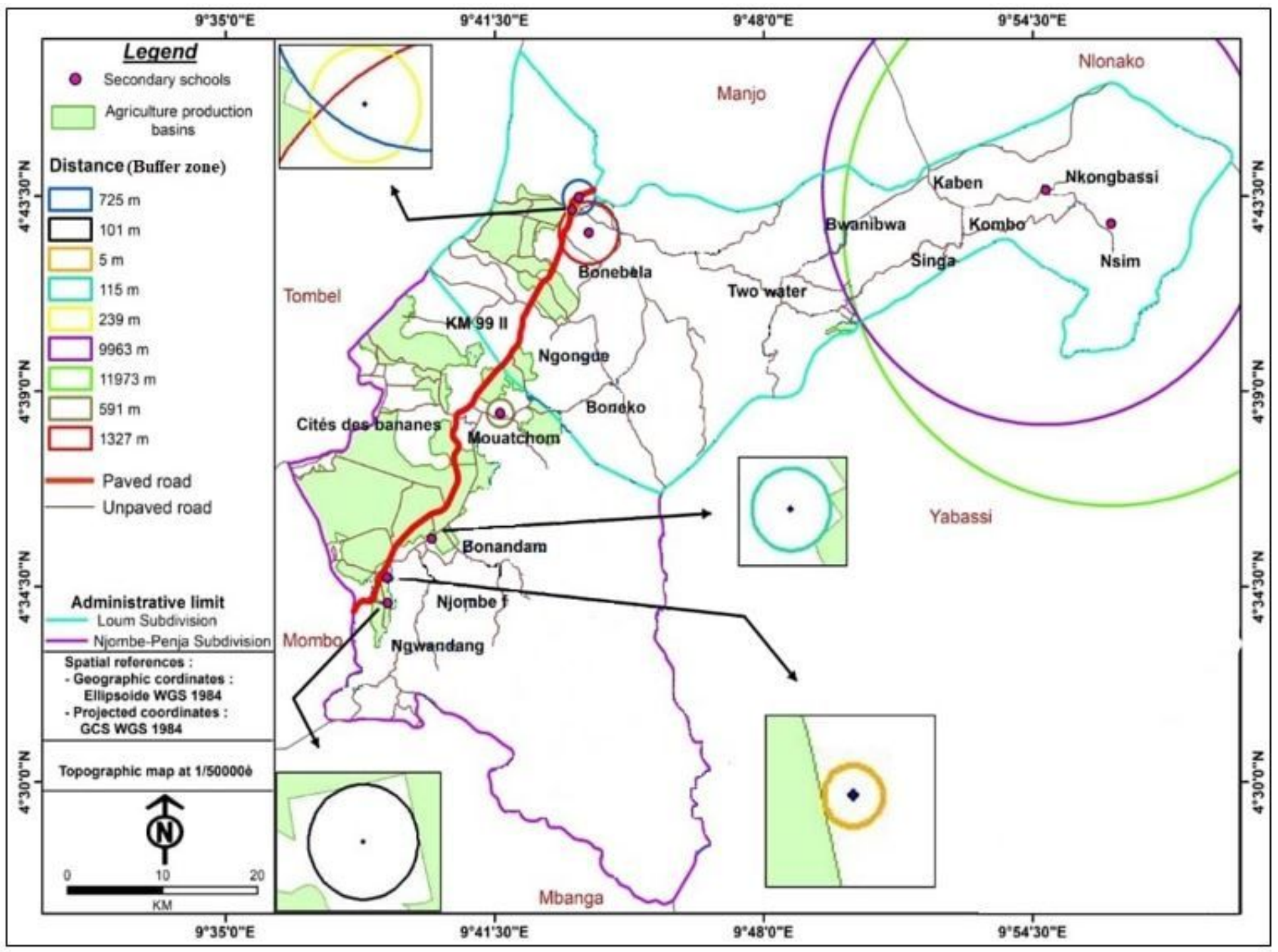

Figure 2

Proximity of schools to the PHP. Source: National Institute of Cartography, 2018 and field work. Drawn by: Ernest Nkemleke. Note: The designations employed and the presentation of the material on this map do not imply the expression of any opinion whatsoever on the part of Research Square concerning the legal status of any country, territory, city or area or of its authorities, or concerning the delimitation of its frontiers or boundaries. This map has been provided by the authors. 


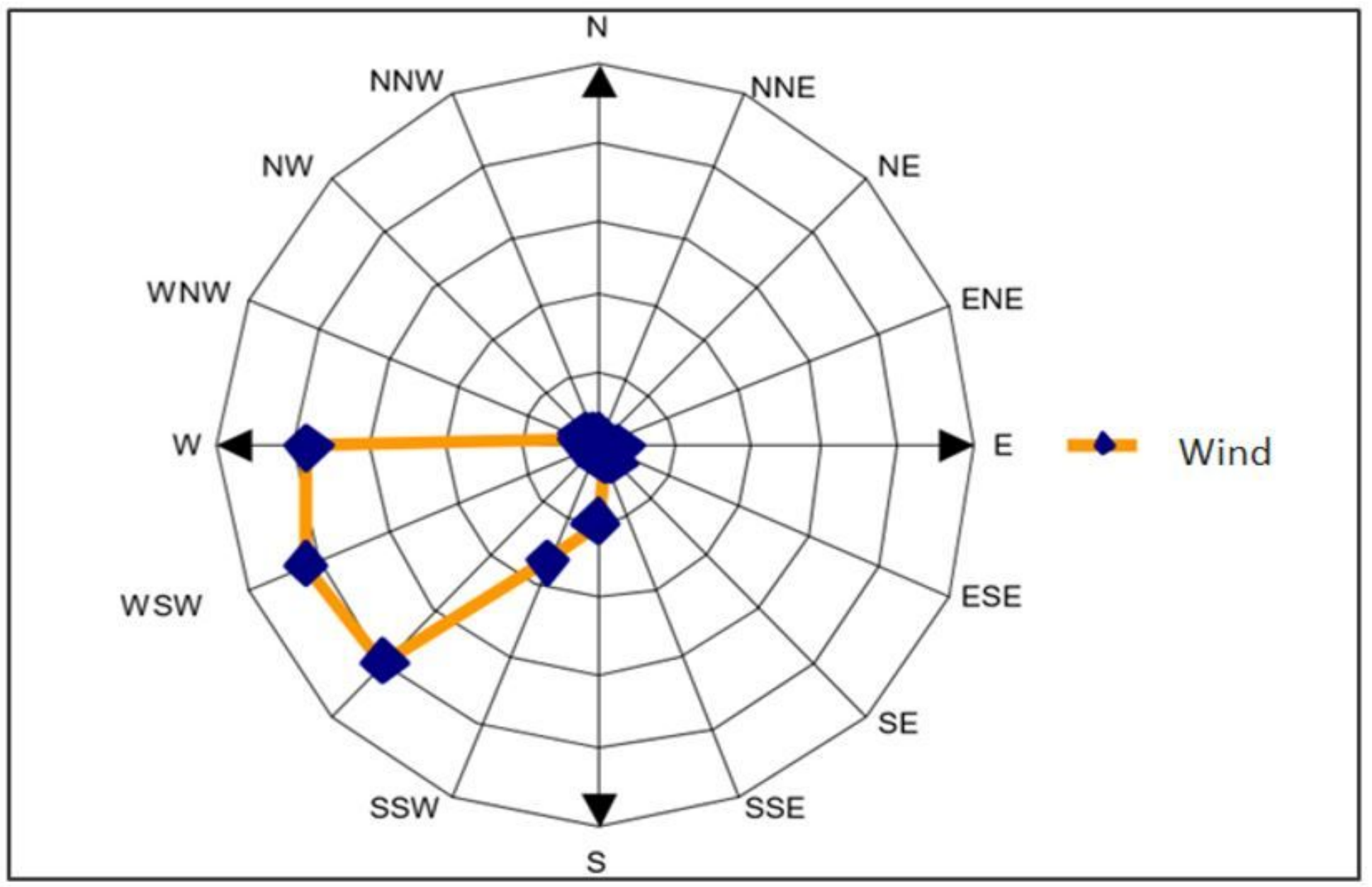

Figure 3

Wind rose of Njombe-Penja with prevailing winds from WSW direction. Source: Modified from Feumba, 2015 


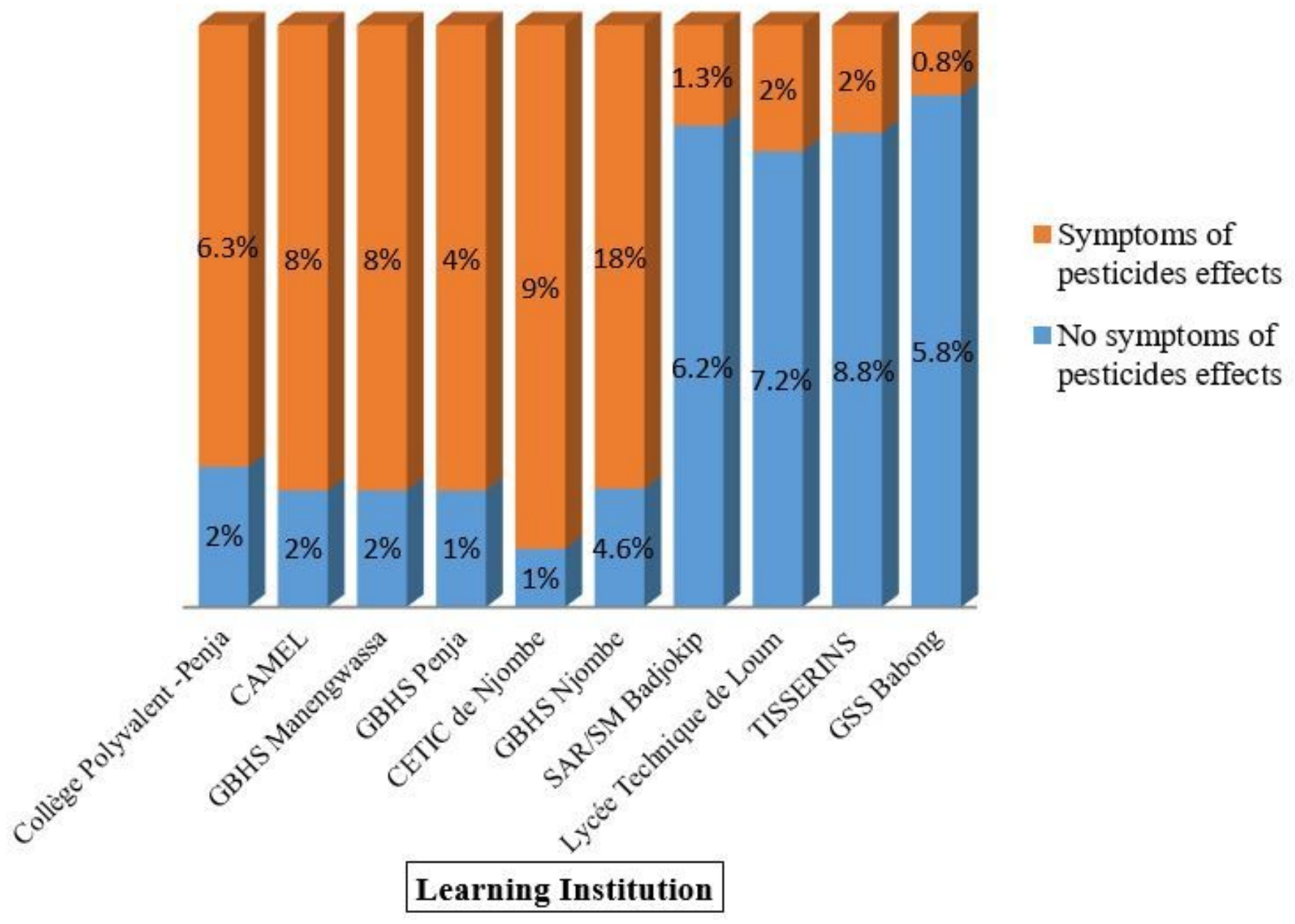

Figure 4

Symptoms of pesticide harmful effects across schools. Source: Field work, 2019 